\title{
Pengaruh Media Sosial “Instagram” Di Masa Pandemi Covid- 19 terhadap Kekerasan Berbasis Gender Online
}

\author{
Fitria Cita Dirna \\ Jurusan Kehutanan, Sekolah Tinggi Pertanian Sriwigama, Palembang \\ ${ }^{\star}$ Penulis Koresponden: citadirna@gmail.com
}

\section{ABSTRAK}

Kekerasan Berbasis Gender Online (KBGO) merupakan salah satu jenis kasus baru dalam Kekerasan Berbasis Gender yang saat ini mulai banyak dilaporkan kepada Komnas Perempuan. Kekerasan ini dapat terjadi karena difasilitasi oleh internet serta teknologi. Instagram merupakan media sosial yang memiliki banyak jumlah pengguna sehingga menjadi salah satu wadah terjadinya kasus KBGO. Penulisan artikel ini bertujuan untuk menganalisis pengaruh media sosial instagram terhadap kasus KBGO di masa pandemi COVID-19 serta menganalisis upaya-upaya apa saja yang dapat dilakukan dalam menangani kasus KBGO. Metodologi yang digunakan dengan pendekatan deskriptif analisis telaah pustaka sebanyak 21 literatur yang berkaitan dengan KBGO, media sosial, instagram, dan masa pandemi COVID-19 di Indonesia. Hasil analisis menunjukkan bahwa instagram berpengaruh terhadap peningkatan kasus KBGO di masa pandemi COVID-19. Adapun upaya yang dilakukan untuk menangani kasus KBGO seperti membuat akun khusus di instagram, sebagai wadah untuk korban KBGO berbagi kisah yang pernah dialaminya, melakukan seminar daring (webinar) di masa pandemi COVID19, dan membuat kampanye dengan poster di instagram. Secara keseluruhan, peristiwa pelecehan dengan komentar kasar serta pelanggaran privasi merupakan jenis kasus KBGO yang banyak terjadi diinstagram..

Kata Kunci: instagram; KBGO; media sosial; pandemi COVID-19

\section{ABSTRACT}

Online Gender-Based Violence (KBGO) is a new type of case in Gender-Based Violence, which is currently being reported to Komnas Perempuan. This violence can occur because it is facilitated by the internet and technology. Instagram is a social media that has a large number of users so that it is one of the places for the KBGO case to occur. The purpose of writing this article is to analyze the influence of social media Instagram on KBGO cases during the COVID-19 pandemic and to analyze what efforts can be made in dealing with KBGO cases. The methodology used is a descriptive approach to analyzing literature review as much as 21 literature related to KBGO, social media, instagram, and the COVID- 19 pandemic in Indonesia. The results of the analysis show that Instagram has an effect on the increase in KBGO cases during the COVID-19 pandemic. Efforts are being made to handle the KBGO case, such as creating a special account on instagram as a forum for $K B G O$ victims to share stories they have experienced, conducting online seminars (webinars) during the COVID-19 pandemic, and creating campaigns with posters on Instagram. Overall, incidents of harassment with harsh comments and violations of privacy are the most common types of KBGO cases on Instagram.

Kata Kunci: instagram; KBGO; social media; COVID-19 pandemic

\section{PENDAHULUAN}

Kekerasan Berbasis Gender (KBG) merupakan kekerasan yang melibatkan laki-laki dan perempuan sebagai akibat dari timpangnya distribusi kekuasaan antara laki-laki dan perempuan, serta yang menjadi korban biasanya adalah perempuan. Menurut catatan laporan Komnas Perempuan dalam lima tahun terakhir, jumlah kasus Kekerasan Berbasis Gender (KBG) selalu meningkat dan spektrum kekerasan terhadap perempuan semakin meluas. Salah satu jenis kasus baru dalam KBG yang saat ini mulai banyak dilaporkan kepada Komnas Perempuan adalah Kekerasan Berbasis Gender Online (KBGO). 
Kekerasan Berbasis Gender Online (KBGO) adalah segala bentuk tindakan yang membuat seseorang merasa tidak aman atau menyerang gender seksualitas seseorang dengan difasilitasi oleh internet serta teknologi. ${ }^{1}$ Kekerasan Berbasis Gender Online merupakan Technology-Facilitated Gender Based Violence (TFGBV). Kekerasan ini terdiri dari penguntitan (stalking), penindasan (bullying), pelecehan seksual (sexual harassment), pencemaran nama baik (defamation), ujaran kebencian (hate speech), eksploitasi (exploitation), dan gender trolling. ${ }^{2}$

Di Indonesia, kasus KBGO ini terus mengalami peningkatan selama enam tahun terakhir. Pada tahun 2019 terdapat 241 kasus KBGO, kemudian naik menjadi 940 kasus yang dilaporkan ke Komnas Perempuan pada tahun $2020 .{ }^{3}$ Bentuk kejahatan yang populer dilaporkan yaitu menyebarkan foto atau video ke media sosial hingga ke situs web pornografi. Penyebaran foto dan video tersebut biasanya dilakukan dengan atau tanpa ancaman. Peningkatan laporan terkait kasus KBGO ini dipengaruhi oleh mudahnya akses terhadap penggunaan internet. Semakin luas jangkauan internet, semakin canggih perkembangan dan penyebaran di bidang teknologi, sehingga kasus KBGO semakin tinggi.

Saat ini, pengguna teknologi khususnya internet di Indonesia setiap tahunnya mengalami peningkatan. Setiap hari banyak pengguna yang mulai mengakses dan menggunakan internet dengan berbagai macam kepentingan. Pada tahun 2020, terjadi peningkatan sebesar 73,7\% pengguna internet baru atau setara dengan 196,7 juta pengguna akibat dari Pandemi COVID-19. ${ }^{4}$ Peningkatan penggunaan internet pada masa pandemi COVID-19 disebabkan oleh pembelajaran online dan kebijakan bekerja dari rumah (work from home).

Namun, penggunaan internet di masa pandemi COVID-19 juga berpengaruh terhadap peningkatan KBGO. Selama masa pandemi COVID-19 angka kasus KBGO meningkat drastis hingga menempati posisi kedua setelah kasus Kekerasan Dalam Rumah Tangga (KDRT). Setiap hari akan ada satu kasus yang dilaporkan ke LBH APIK Jakarta terkait KBGO. ${ }^{5}$ Penggunaan internet yang meningkat di masa pandemi COVID-19 berbanding lurus dengan peningkatan penggunaan media sosial, khususnya instagram. Instagram merupakan salah satu media sosial yang banyak digunakan oleh masyarakat untuk berkomunikasi secara online. Pada bulan Februari 2021 jumlah total pengguna instagram sebesar 82.120 .000 yang merupakan $29.9 \%$ dari seluruh populasi penduduk di Indonesia. Sebanyak $52.6 \%$ mayoritasnya adalah perempuan dan $47.4 \%$ adalah laki-laki. ${ }^{6}$ Tingginya jumlah pengguna instagram untuk perempuan diduga dapat menjadi salah satu faktor kasus KBGO banyak terjadi di instagram.

Berdasarkan hal-hal tersebut di atas, maka penulisan artikel ini bertujuan untuk menganalisis pengaruh media sosial instagram terhadap kasus KBGO di masa pandemi COVID-19 serta menganalisis upaya-upaya apa saja yang dapat dilakukan dalam menangani kasus KBGO.

\footnotetext{
1 SAFEnet, "Sebuah Panduan", 4.

2 Hinson, dkk, "Technology-Facilitated Gender Based Violence."

3 Komnas Perempuan, Catahu 2021, 2.

${ }^{4}$ APJII, "Survei."

${ }^{5}$ LBH APIK Jakarta, "Siaran Pers."

6 Napoleon Cat, “Instagram."
} 


\section{TINJAUAN PUSTAKA}

\section{Kekerasan Berbasis Gender Online (KBGO)}

Kekerasan Berbasis Gender Online (KBGO) adalah kekerasan jenis baru yang terjadi akibat perkembangan teknologi. Jenis kekerasan ini masih belum banyak diketahui oleh masyarakat Indonesia. Banyak masyarakat yang masih awam bila ditanya tentang pengertian kekerasan berbasis gender atau kekerasan berbasis gender online. Masyarakat banyak yang belum memahami bentukbentuk kekerasan yang dapat menyerang identitas gender di ranah digital (online), khususnya perempuan dan gender minoritas lainnya.

Bentuk-bentuk kekerasan berbasis gender online yang dilaporkan kepada Komnas Perempuan terbagi menjadi 8 bentuk, yaitu pendekatan untuk memperdaya (cyber grooming), pelecehan online (cyber harassment), peretasan (hacking), konten ilegal (illegal content), pelanggaran privasi (infringement of privacy), ancaman distribusi foto/video pribadi (malicious distribution), pencemaran nama baik (online defamation), dan rekrutmen online(online recruitment). Selanjutnya, berdasarkan Internet Governance Forum menjelaskan bahwa kekerasan berbasis gender online yaitu spektrum perilaku, termasuk penguntitan, pengintimidasian, pelecehan seksual, pencemaran nama baik, ujaran kebencian dan eksploitasi. ${ }^{7}$

Di sisi lain, beberapa aktivitas yang terjadi dalam kehidupan sehari-hari juga dapat digolongkan menjadi KBGO, di antaranya adalah sebagai berikut: a) pelanggaran privasi b) pengawasan dan pemantauan c) perusakan reputasi/kredibilitas d) pelecehan (yang dapat disertai dengan pelecehan offline) e) ancaman dan kekerasan langsung f) serangan yang ditargetkan ke komunitas tertentu. ${ }^{8}$

Kasus KBGO yang dilaporkan ke Komnas Perempuan mengalami peningkatan yaitu sebanyak 241 kasus pada tahun 2019 naik menjadi 940 kasus di tahun 2020. Lembaga Layanan yang menangani kasus KBGO juga mencatat bahwa pada tahun 2019 terdapat 126 kasus, mengalami peningkatan menjadi 510 kasus pada tahun 2020. Peningkatan kasus KBGO sudah sepatutnya menjadi perhatian serius untuk semua pihak. ${ }^{9}$

\section{Media Sosial}

Media sosial adalah sebuah media online dimana para penggunanya dapat dengan mudah berpartisipasi, berbagi, dan menciptakan isi seperti blog, jejaring sosial, wiki, forum dan dunia virtual. Blog, jejaring sosial, dan wiki merupakan contoh dari bentuk media sosial yang paling umum digunakan oleh masyarakat di seluruh dunia. Selain itu juga, media sosial adalah media online yang mendukung interaksi sosial, serta media sosial menggunakan teknologi berbasis web yang mengubah komunikasi menjadi dialog interaktif. ${ }^{10}$ Media sosial merupakan kumpulan perangkat lunak yang

\footnotetext{
7 SAFEnet, “Sebuah Panduan”, 5.

8 SAFEnet, "Sebuah Panduan”, 6-7.

9 Komnas Perempuan, Catahu 2021, 2.

10 Anang Sugeng Cahyono, “Pengaruh Media Sosial,” 142.
} 
memungkinkan individu maupun komunitas untuk dapat berkumpul, berbagi, berkomunikasi, serta dapat berkolaborasi dalam kasus tertentu. ${ }^{11}$

Selanjutnya, Villanueva mendefinisikan media sosial sebagai bagian internet yang memberikan kekuasaan setiap orang untuk menginformasikan gagasannya kepada orang lain, secara interpersonal, ataupun ke banyak orang. ${ }^{12}$ Ada enam jenis media sosial yaitu proyek kolaborasi (contohnya, wikipedia), blog dan microblogs (contohnya, twitter), komunitas konten (contohnya, youtube), situs jaringan sosial (contohnya facebook, instagram), virtual game (contohnya world of warcraft), dan virtual social (contohnya, second life). ${ }^{13}$

Saat teknologi internet dan handphone semakin maju, maka media sosial pun turut berkembang dengan pesat. Kini untuk mengakses instagram, youtube, whatsapp misalnya, dapat dilakukan dimana dan kapan saja hanya dengan menggunakan sebuah handphone. Demikian mudah dan cepatnya seseorang bisa mengakses media sosial mengakibatkan munculnya fenomena besar terhadap arus informasi, tidak hanya di negara-negara maju tetapi juga di Indonesia. Hal ini membuat media sosial mulai tampak menggantikan peranan media massa konvensional dalam menyebarkan berita-berita.

Instagram

Instagram merupakan jejaring sosial yang sangat populer untuk digunakan mengunggah foto. Pengguna mengunggah foto digital, mengaplikasikan filter untuk mengedit penampilannya, kemudian membagikan foto tersebut ke pengguna lainnya. Instagram telah menjadi aplikasi tempat berbagi foto terkemuka untuk pengguna ponsel dan telah memiliki lebih dari 200 juta pengguna yang teregistrasi.

Sejarah instagram dimulai saat Kevin Systrom dan Michel "Mike" Krieger mulai menggunakan instagram di bulan Oktober 2010 sebagai Burbn, sebuah program yang didukung HTML-5 untuk ponsel. Setelah didanai oleh berbagai sumber, termasuk Baseline Venturers dan Andreessen Horowitz, berkembang menjadi instagram, sebuah nama yang mengkombinasikan nama dari dua metode komunikasi. Saat pertama kali diumumkan, instagram mencapai 1 juta anggota setelah 2 bulan beroperasi. Kurang dari satu tahun kemudian, lebih dari 150 juta foto telah diunggah ke situs. Pada tahun 2011, situs instagram mencapai 10 juta pengguna, dan Apple memberi instagram gelar "The Iphone App of The Year". ${ }^{14}$

Pengguna instagram di Indonesia pada bulan februari 2021 berdasarkan data dari Napoleon Cat terdapat 82.120.000 jumlah pengguna. Jumlah ini dihitung sebesar 29.9\% dari jumlah populasi, dimana mayoritas penggunanya adalah perempuan yaitu sebesar $52.6 \%$, Rentang usia pengguna instagram terbanyak yaitu berada pada usia 18 - 24 tahun yang merupakan rentang usia terbesar dalam grup pengguna yaitu $30.000 .000 .{ }^{15}$

\footnotetext{
11 Boyd, "Social Media."

12 Winkelman, The Social Media Revolution ?, 151-175.

13 Kaplan, and Haenlein, "Users of The World," 59-68.

14 Kjell H. Landsverk, "The Instagram Handbook" 1-3.

15 Napoleon cat, “Instagram.”
} 


\section{Pandemi Covid-19 Di Indonesia}

Pada tahun 2019 dunia dihebohkan dengan peristiwa munculnya suatu penyakit baru yang meresahkan masyarakat yang dikenal dengan virus corona (COVID-19). Virus tersebut muncul pertama kali di Wuhan, Tiongkok. Peristiwa ini terjadi diduga virus menyebar akibat paparan di pasar makanan laut huanan yang banyak menjual jenis hewan hidup. Penyakit ini dengan cepat menyebar ke wilayah lain di China, dan secara global juga terjadi di negara lain di enam benua. ${ }^{16}$ Pada tanggal 3 Januari 2020, Pusat Pengendalian dan Pencegahan Penyakit di Wuhan melakukan identifikasi sampel cairan dari salah satu pasien yang selanjutnya dikonfirmasi sebagai penyebab penyakit COVID-19. ${ }^{17}$ Selanjutnya, pada tanggal 11 Januari 2020, Organisasi Kesehatan Dunia (WHO) memberi nama penyakit ini Coronavirus Disease 2019 (COVID-19). ${ }^{18}$

Coronavirus Disease 2019 (COVID-19) adalah jenis penyakit baru yang belum pernah teridentifikasi terjadi pada manusia. Virus penyebab COVID-19 adalah Sars-CoV-2. Virus ini dapat ditularkan antara manusia dan hewan. Namun, hewan yang menjadi sumber penularan penyakit ini belum dapat diketahui. Penularan COVID-19 dapat terjadi antara manusia melalui percikan bersin/batuk, dan orang yang paling beresiko dapat tertular penyakit ini adalah orang yang melakukan kontak secara langsung dengan pasien COVID-19, ataupun orang yang melakukan perawatan terhadap pasien COVID-19. ${ }^{19}$ Gejala umum yang terjadi bila terinfeksi COVID-19 adalah gangguan pernapasan berat seperti demam, batuk, dan sesak napas. Disisi lain, COVID-19 juga dapat menyebakan pneumonia, gagal ginjal, bahkan kematian. ${ }^{20}$

Pada tanggal 27 Januari 2020, Pemerintah Indonesia mengeluarkan aturan pembatasan perjalanan dari Tiongkok, dan dengan segera melakukan evakuasi terhadap 238 Warga Negara Indonesia (WNI) yang berada di Wuhan. Selanjutnya, Presiden Joko Widodo menyatakan kepada publik untuk pertama kali teridentifikasi dua kasus COVID-19 pada tanggal 2 Maret 2020 di Indonesia. ${ }^{21}$ Pasien yang terkonfirmasi COVID-19 di Indonesia ini diduga tertular akibat kontak langsung dengan seorang Warga Negara Asing (WNA) saat menghadiri suatu acara di Jakarta. Adapun keluhan yang dirasakan pasien setelah pertemuan itu adalah demam, batuk dan sesak nafas yang sangat sesuai dengan gejala dari COVID-19.

Pandemi COVID-19 yang telah ditetapkan sebagai darurat kesehatan global oleh WHO membuat kegiatan manusia sehari-hari menjadi terhambat. Di sisi lain, Pemerintah Indonesia telah banyak melakukan langkah-langkah serta kebijakan untuk mengatasi permasalahan pandemi COVID-19. Salah satu langkah yang dilakukan adalah gerakan "Social Distancing" pada masyarakat. Gerakan ini mengharuskan masyarakat untuk menjaga jarak aman dengan orang lain minimal dua meter, tidak

\footnotetext{
16 Dong Y, dkk. “Epidemiology,"1-12.

17 Tan W, dkk., "A novel," 61-62.

18 WHO, "Critical preparedness,"1-2.

19 Kemenkes RI, "Pertanyaan dan Jawaban terkait COVID-19."

20 Tosepu, dkk, “Correlation," 1-5.

21 Djalantae, dkk. “Review,"1-10.
} 
melakukan kontak secara langsung dengan orang lain, dan menghindari pertemuan massal. Gerakan ini dibuat dengan tujuan untuk memutus rantai penularan COVID-19. ${ }^{22}$

Upaya lain yang sedang dilakukan oleh pemerintah saat ini adalah dengan mengeluarkan kebijakan pelaksanaan Vaksinasi COVID-19. Adapun instruksi Presiden untuk program vaksinasi COVID-19 antara lain (1) Vaksin COVID-19 diberikan secara gratis dan masyarakat tidak dikenakan biaya sama sekali, (2) seluruh jajaran kabinet, kementerian lembaga, dan pemerintah daerah agar memprioritaskan program vaksinasi pada tahun anggaran 2021, (3) memprioritaskan dengan merelokasi anggaran lain terkait ketersediaan dan vaksinasi secara gratis, (4) Presiden menjadi orang pertama yang mendapatkan vaksin. Hal ini dilakukan untuk memberikan kepercayaan dan keyakinan kepada masyarakat bahwa vaksin yang digunakan tersebut aman, (5) masyarakat dihimbau untuk terus menjalankan disiplin 3M (mencuci tangan, menggunakan masker, dan menjaga jarak).

\section{KERANGKA PIKIRAN DAN METODOLOGI}

\section{Kerangka Pikiran}

Kerangka pikiran bertujuan untuk menjelaskan dan memprediksi fenomena yang terjadi. Adapun kerangka pikiran pada penulisan ini seperti pada Gambar 1.

\section{Metodologi}

Metodologi yang digunakan dengan pendekatan deskriptif analisis telaah pustaka sebanyak 21 literatur yang berkaitan dengan KBGO, media sosial, instagram, dan masa pandemi COVID-19 di Indonesia. Metode ini berusaha untuk menjelaskan bagaimana situasi yang terjadi saat pandemi COVID-19 di Indonesia memberi dampak dalam penggunaan internet. Peningkatan penggunaan internet masyarakat Indonesia diakibatkan oleh munculnya kebijakan yang diterapkan oleh pemerintah pada masa COVID-19 yaitu peraturan belajar daring dan work from home. Hal ini menyebabkan tingginya jumlah penggunaan internet pada masyarakat khususnya media sosial yang berpengaruh pada munculnya kekerasan berbasis gender online.

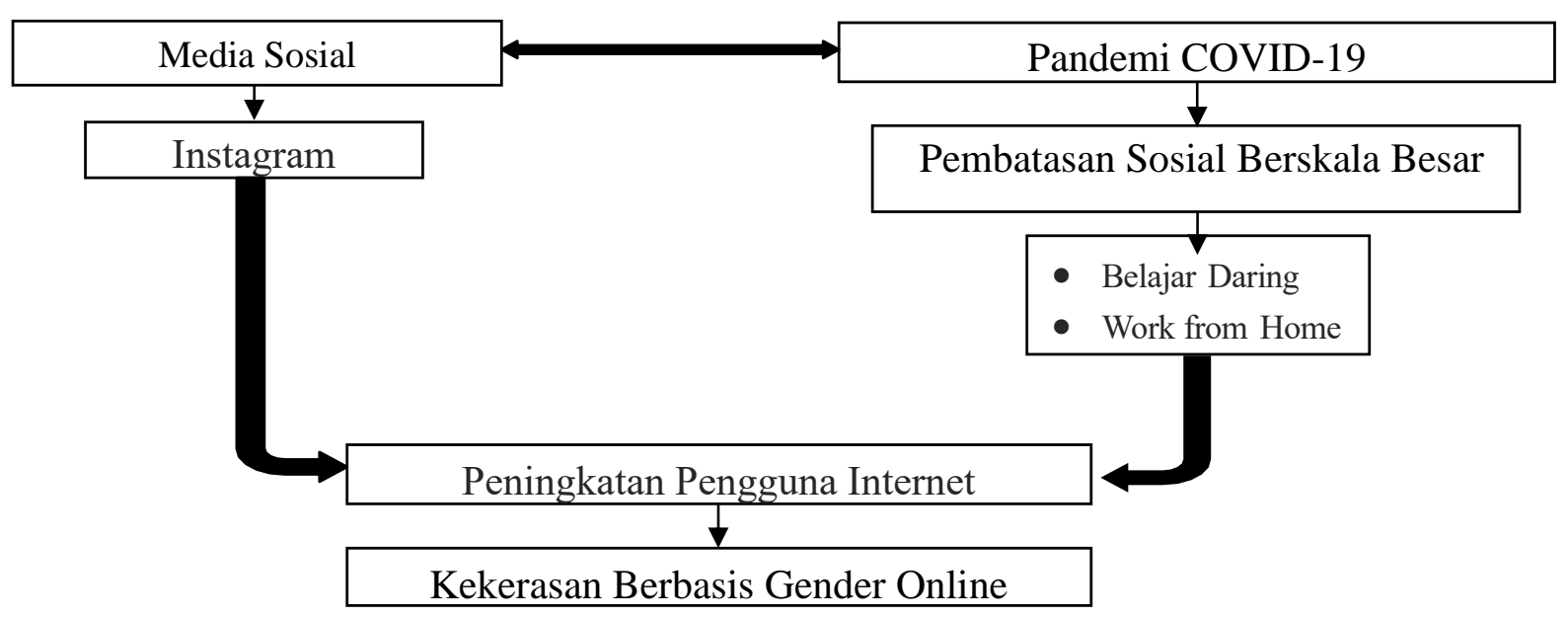

Gambar 1. Kerangka pikiran hubungan antara media sosial dan pandemi

22 Buana, “Analisis Perilaku,” 217-226. 


\section{HASIL DAN PEMBAHASAN}

Kekerasan Berbasis Gender Online (KBGO) di Indonesia pada Masa Pandemi COVID-19

Pada tahun 2020, jumlah kasus KBGO berdasarkan provinsi dan lembaga layanan pada Komnas Perempuan ditunjukkan pada Gambar 2 dan Gambar 3.

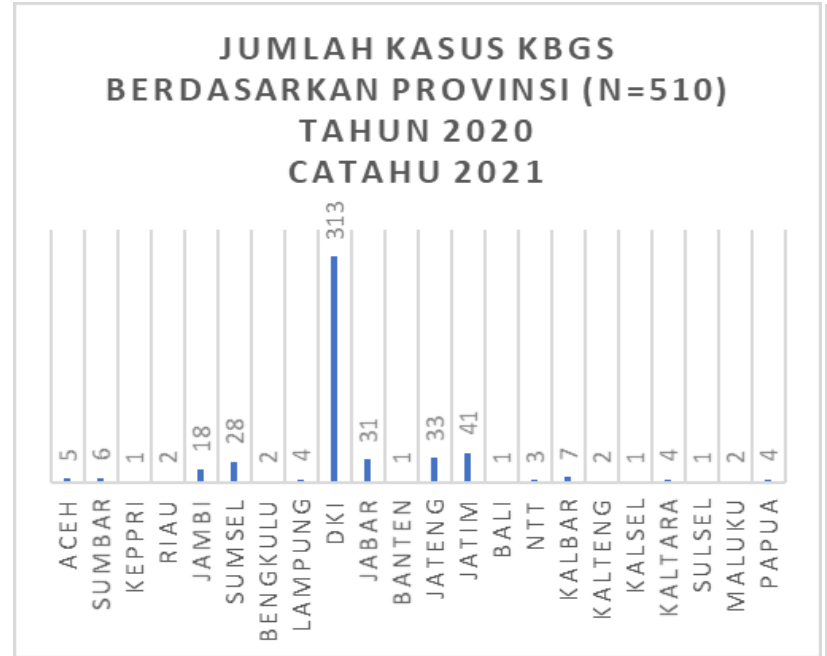

Gambar 2. Kasus KBGO Berdasarkan Provinsi Tahun 2020
JUMLAH KASUS KBGS

BERDASAR LEMBAGA

LAYANAN $(\mathrm{N}=510)$

CATAHU 2021

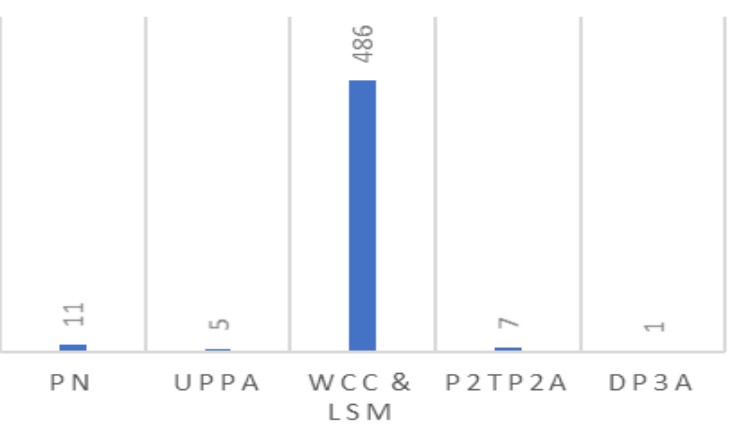

Gambar 3. Kasus KBGO Berdasarkan

Lembaga Layanan

Gambar 2 menunjukkan bahwa kasus KBGO tertinggi terjadi di Provinsi DKI Jakarta dengan total laporan sebanyak 313 kasus, lalu dari provinsi Jawa Timur sebanyak 41 kasus, Provinsi Jawa Tengah 33 kasus, serta Provinsi Sumatera Selatan sebanyak 28 kasus. Selanjutnya, pada Gambar 3 jumlah lembaga yang melaporkan kasus terbanyak yaitu lembaga WCC dan LSM sebanyak 486 kasus. Jenis kasus yang dilaporkan beragam dan masih dilakukan oleh orang terdekat korban, seperti: pacar, mantan pacar, dan suami korban. Pihak lain juga dapat menjadi pelaku kekerasan seperti teman media sosial (orang yang belum dikenal sebelumnya).

Gambar 4 menjelaskan jumlah kasus yang terjadi berdasarkan jenisnya, dengan kasus malicious distribution merupakan jenis kasus laporan tertinggi sebanyak 370 kasus. Malicious distribution yaitu penggunaan teknologi untuk memanipulasi dan mendistribusikan objek ilegal dan fitnah tentang korban, seperti mengancam dan/atau menyebarkan foto/video pribadi. Kegiatan ini biasanya dilakukan agar korban tetap melakukan apa yang diinginkan oleh pelaku, seperti tidak melapor kepada orang lain, tidak meninggalkan pelaku (dalam hubungan pacaran), terus berhubungan seksual dengan pelaku, dan pemerasan. Peningkatan kasus KBGO pada tahun 2020 juga dapat disebabkan oleh kondisi COVID-19 yang membatasi pertemuan di dunia nyata dan meningkatkan intensitas penggunaan platform digital (online). Kasus KBGO yang terus terjadi menimbulkan rasa tidak aman untuk perempuan dalam menggunakan teknologi. 


\section{Jenis Kekerasan Berbasis Gender Siber berdasar \\ Data Lembaga Layanan Tahun 2020 \\ CATAHU 2021}

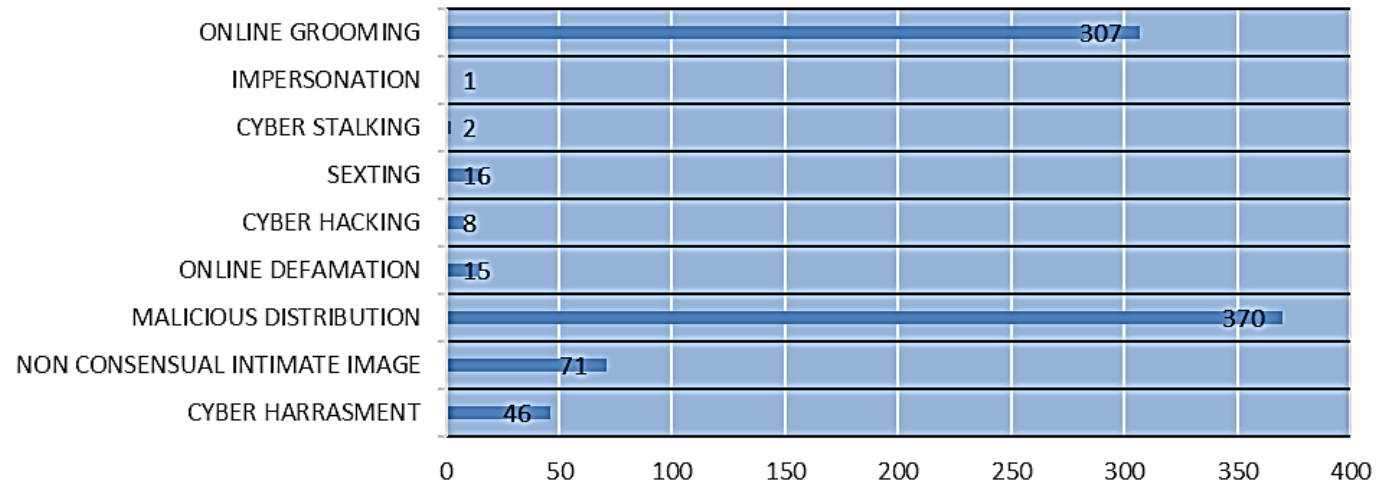

Gambar 4. Jenis Kekerasan Berbasis Gender Online Data Lembaga Layanan Tahun 2020 (Sumber Catatan Tahunan 2021)

\section{Penggunaan Media Sosial Instagram di Masa Pandemi COVID-19}

Instagram merupakan salah satu jenis media sosial yang saat ini banyak digunakan oleh masyarakat secara global. Berdasarkan data yang dirilis oleh Napoleon Cat, pengguna instagram terus meningkat hingga saat ini. Pada saat awal pandemi COVID-19 jumlah pengguna instagram sebanyak 64 juta orang pada bulan Maret 2020 dan 84 juta orang pada bulan Februari 2021. Adapun jumlah pengguna Instagram di Indonesia pada bulan Januari-Mei 2020 ditunjukkan pada Gambar 5.

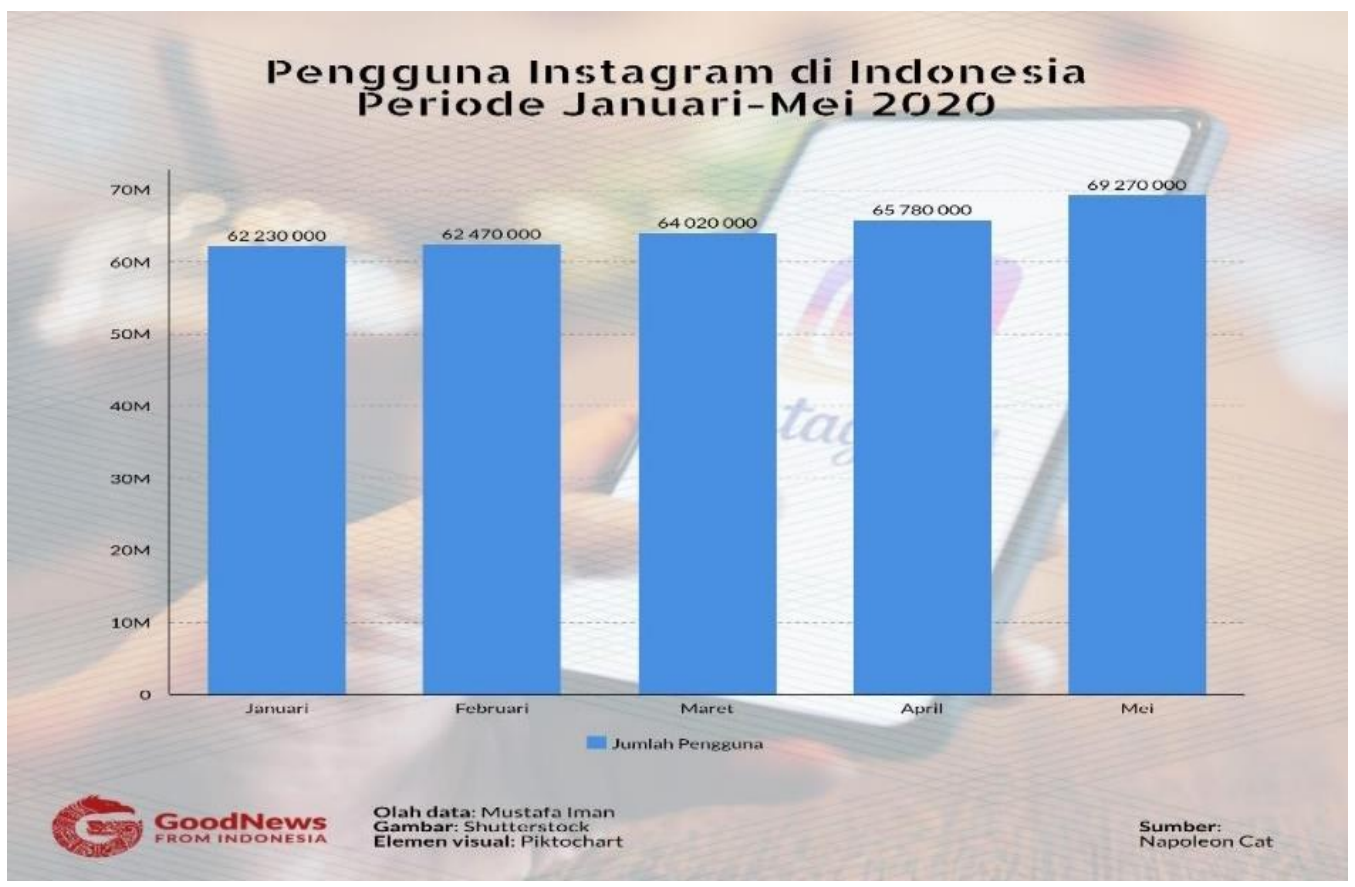

Gambar 5. Pengguna Instagram di Indonesia Periode Januari-Mei 2020 (Sumber: Napoleon Cat) 
Gambar 5 menunjukkan pengguna instagram di Indonesia periode Januari-Mei 2020 mengalami peningkatan setiap bulannya. Pada saat kasus COVID-19 diumumkan menjadi wabah global termasuk di Indonesia, pada bulan maret jumlah pengguna instagram sebesar 64 juta. Jumlah ini meningkat dibandingkan dari bulan sebelumnya dan terus mengalami peningkatan sampai dengan bulan Mei 2020 sebesar 69 juta pengguna.

Jumlah pengguna instagram terus meningkat pada bulan Juni 2020 hingga Desember 2020. Pada bulan Januari 2021 dan Februari 2021, jumlah pengguna instagram mengalami penurunan bila dibandingkan dengan bulan sebelumnya, hal ini diduga disebabkan oleh aktivitas yang mulai kembali banyak dilakukan secara langsung (nyata) dengan tetap mengikuti peraturan protokol kesehatan. Namun, bila dibandingkan dengan pengguna instagram pada masa sebelum pandemi COVID-19, jumlah pengguna di bulan februari 2021 tetap lebih tinggi dari masa sebelum pandemi COVID-19. Adapun jumlah pengguna Instagram di Indonesia pada bulan Juni 2020-Februari 2021 ditunjukkan pada Gambar 6.

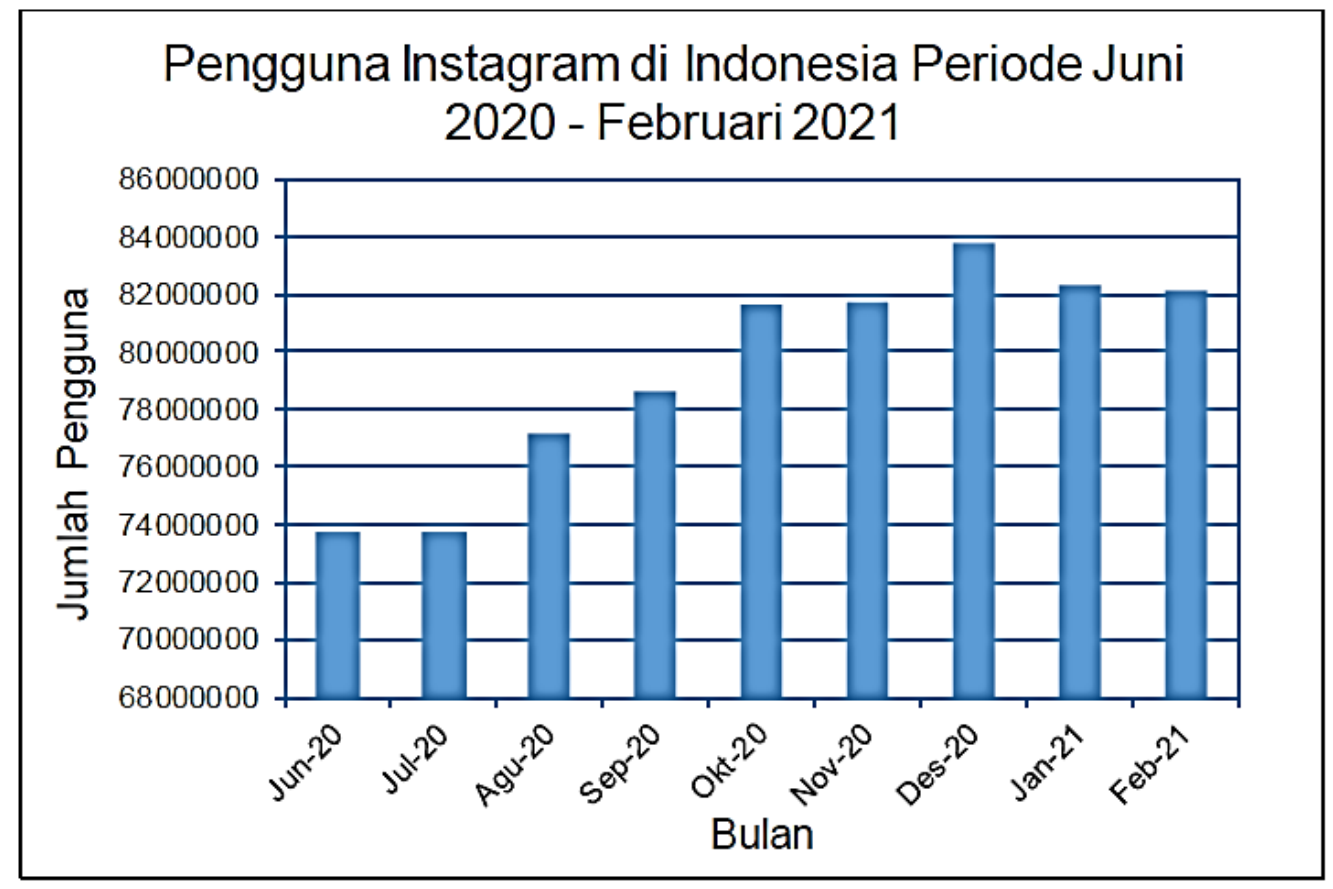

Gambar 6. Pengguna Instagram di Indonesia Periode Juni 202-Februari 2021

(Sumber: Napoleon Cat)

Pengguna instagram juga diklasifikasikan berdasarkan usia, dan gender. Berdasarkan jumlah total pengguna instagram pada bulan Februari 2021 sebesar 82.120.000 merupakan 29.9\% dari seluruh populasi penduduk di Indonesia. Sebanyak 52.6\% mayoritasnya adalah perempuan dan 47.4\% adalah laki-laki. Rentang usia pengguna instagram 18-24 merupakan rentang usia tertinggi dengan jumlah sebesar 30.000.000 pengguna instagram. Jumlah pengguna Instagram berdasarkan usia dan gender di Indonesia pada bulan Februari 2021 ditunjukkan pada Gambar 7. 


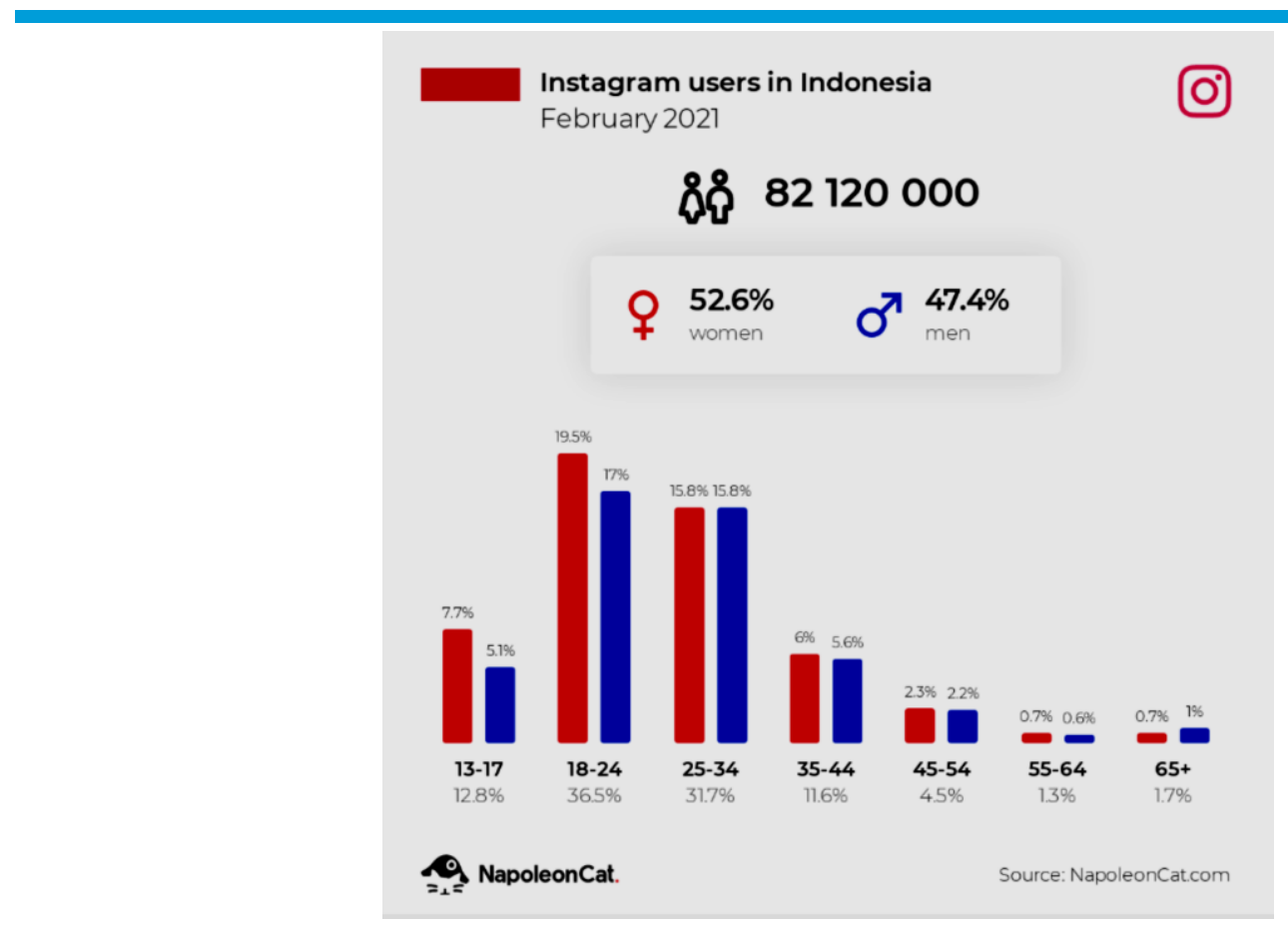

Gambar 7. Jumlah pengguna Instagram berdasarkan usia dan gender di Indonesia pada bulan Februari 2021

(Sumber : Napoleon Cat)

\section{Contoh Kasus KBGO yang terjadi di Instagram pada Masa Pandemi COVID-19}

Jumlah pengguna instagram yang semakin meningkat setiap bulan selama masa pandemi COVID19, dengan mayoritas pengguna adalah perempuan tentu menjadi salah satu faktor munculnya KBGO di instagram. Misalnya, pada contoh kasus yang pernah viral terjadi di Indonesia pada bulan Agustus 2020. Pada saat itu, semua media sosial khususnya pengguna instagram ramai memberitakan kasus seorang artis yaitu Adhisty Zara atau yang lebih dikenal dengan Zara JKT48. Zara terlibat video mesra dengan kekasihnya yaitu Zaki Pohan.

Peristiwa ini berawal dari Zara yang menggunggah sendiri video mesra tersebut di akun instagramnya (@zaraadhsty) yaitu di instagram story. Video berdurasi 15 detik tersebut memperlihatkan keduanya sedang bercanda dan tertawa, namun tak lama kemudian sang kekasih meraba bagian payudara Zara, dan Zara terlihat tidak marah namun malah tertawa.

Selang waktu selama 43 detik video tersebut diunggah, Zara kemudian menyadari bahwa apa yang dilakukannya adalah salah, dan langsung menghapus video tersebut dari akun instagramnya. Namun, sayangnya video tersebut sudah terlebih dahulu di rekam oleh oknum-oknum yang tidak bertanggung jawab untuk terus disebarkan ke media sosial lainnya. Perilaku ini jelas merugikan Zara, yang kemudian langsung menutup kolom komentar pada semua foto yang diunggah di instagramnya, untuk menghindari bullying dan hate speech dari masyarakat. Di sisi lain, Ibunda, Kakak, dan Ayahnya juga tidak bisa menghindar dari serangan bullying dan hate speech dari masyarakat. Adapun contoh bullying dan hate speech dari masyarakat pada kasus Zara dapat dilihat pada Gambar 8. 
@zaraadhsty

Remas gratis punya nya

4 jam 16 suka Balas

Harusnya anda mengajari Anak anda tata cara berperilaku sopan apalagi anak ANDA ini sebuah public figure yg notabene followersnya didominasi oleh kaum muda, coba lihat snapgramnya? Apakah layak? Apakah perbuatannya patut dicontoh? Im not judging, but people needs to behave nowdays

3 jam 68 suka Balas

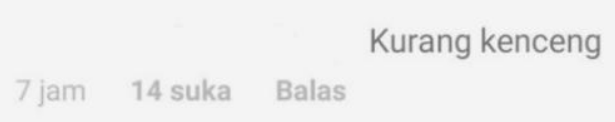

nikah sama gojek aja, biar ga di grab grab tan kak zaranya. saya ganyangka sih. asli (6)

6 jam 29 suka Balas

Dari awal jg gw udh gak suka sm dia gatau knp kaya sok cute gtu

5 jam 61 suka Balas

Gambar 8. Komentar Bullying dan Hate Speech pada Kasus Zara JKT48

(Sumber: Instagram (@mrssaladin)

Pada kasus yang dialami oleh Zara, bullying dan hate speech merupakan salah satu jenis dari kasus KBGO yaitu pelecehan, dalam hal ini pelecehan yang terjadi menggunakan komentar kasar di media sosial instagram. Selain itu, kasus ini juga dapat digolongkan menjadi kasus pelanggaran privasi yaitu penyebaran konten pribadi yang dilakukan oleh orang lain. Walaupun Zara juga terlibat dalam penyebaran yang tidak dilakukannya secara sengaja, seharusnya masyarakat yang menjadi followersnya di instagram, yang sudah melihat videonya sebelum dihapus oleh Zara, sebaiknya tidak merekam dan menyebarluaskan ke media sosial lainnya.

Selanjutnya, kasus KBGO khususnya pelanggaran privasi juga terjadi kembali pada artis di bulan November 2020. Kasus ini terjadi pada seorang artis yaitu Gisella Anastasia dan Michael Yukinobu Diferentes yang terkait kasus video pornografi. Gisella merupakan salah satu korban dari penyebaran konten pribadi yang dilakukan oleh orang lain. Gisella mengakui bahwa peristiwa yang ada di dalam video tersebut terjadi pada tahun 2017. Pada saat itu, Gisella merekam videonya dengan menggunakan ponsel dan hanya disebarkan kepada Michael. Namun, Gisella kehilangan ponsel tersebut yang di dalamnya masih tersimpan data videonya bersama Michael. Selanjutnya, ponsel yang hilang tersebut ditemukan dan disalahgunakan oleh oknum yang tidak bertanggung jawab.

Seiring berjalannya waktu, kasus yang dialami oleh Gisella dilanjutkan pada proses penyelidikan oleh polisi, dengan tujuan untuk menentukan status Gisella dan Michael sebagai pemeran dalam video tersebut. Pada bulan Desember 2020, polisi menetapkan status Gisella dan Michael dari saksi menjadi tersangka, dan keduanya dijerat oleh Pasal 4 Ayat 1 juncto Pasal 29 atau Pasal 8 UU Nomor 44 tentang Pornografi dengan ancaman hukuman 6 bulan atau paling lama 12 tahun penjara. $^{23}$

\footnotetext{
${ }^{23}$ Velarosdela, "Berstatus Tersangka."
} 
Penetapan status tersangka pada Gisella yang dilakukan oleh polisi menimbulkan reaksi dari berbagai pihak, salah satunya adalah Siti Aminah Tardi Komisioner Komnas Perempuan, melalui wawancara dengan wartawan Siti Aminah menjelaskan bahwa dalam kasus Gisella dan Michael, keduanya melakukan hubungan seksual dan merekamnya tidak untuk ditujukan kepentingan industri pornografi atau untuk disebarluaskan. Sehingga, Gisella dan Michael adalah korban dari penyebaran konten intim. Lebih lanjut Siti Aminah menjelaskan bahwa apa yang menimpa Gisella adalah wilayah privasi kehidupannya yang tidak boleh diintervensi oleh negara, dan UU Pornografi sendiri tegas menyatakan bahwa video untuk kepentingan sendiri tidak masuk dalam kategori UU Pornografi, dan yang harus ditetapkan sebagai tersangka adalah penyebar video tersebut. $^{24}$

Hal serupa juga diungkapkan oleh Direktur Eksekutif Institute for Criminal Justice Reform (ICJR) Erasmus Napitupulu yang mengatakan bahwa siapapun tokoh dalam video tidak dapat dipidana. Seseorang yang tidak berniat menyebarluaskan konten pornografi ke publik atau untuk kepentingan diri sendiri tidak melanggar UU Pornografi. "Selama konten tersebut kepentingan pribadi, ketentuan hukum dan konstitusi Indonesia melindungi hak tersebut" tulis Erasmus dalam keterangan pers. Di sisi lain, Erasmus juga mengingatkan kepada penegak hukum agar lebih kritis terhadap kasus semacam ini. Justru yang seharusnya dipahami adalah hak korban yang diduga mirip dalam video asusila. Seharusnya polisi lebih fokus terhadap konten yang merugikan korban agar dapat mencegah penyebaran konten lebih masif di publik dan berusaha menangkap tersangka penyebar video tersebut. ${ }^{25}$

Selanjutnya, jenis kasus KBGO seperti bullying dan hate speech yang dialami oleh Zara, juga dialami oleh selebriti instagram (selebgram) Rachel Vennya, yang membuat heboh masyarakat pada akhir Desember 2020 dengan mengunggah foto tanpa menggunakan hijab di instagramnya. Seperti yang diketahui oleh banyak orang bahwa Rachel Vennya memutuskan untuk berhijab sejak tahun 2018. Namun, Rachel Vennya memutuskan untuk membuka hijabnya pada Desember 2020. Hal ini memunculkan beragam reaksi dari masyarakat, baik perempuan maupun laki-laki ikut memberikan komentar di foto yang diunggah olehnya. Tidak sedikit komentar bermuatan bullying dan hate speech yang diterima Rachel. Adapun contoh komentar bullying dan hate speech dari masyarakat pada kasus Rachel dapat dilihat pada Gambar 9.

\footnotetext{
${ }^{24}$ Komara, "Komnas Perempuan.”

${ }^{25}$ Rizaldy, "Kasus Gisella."
} 


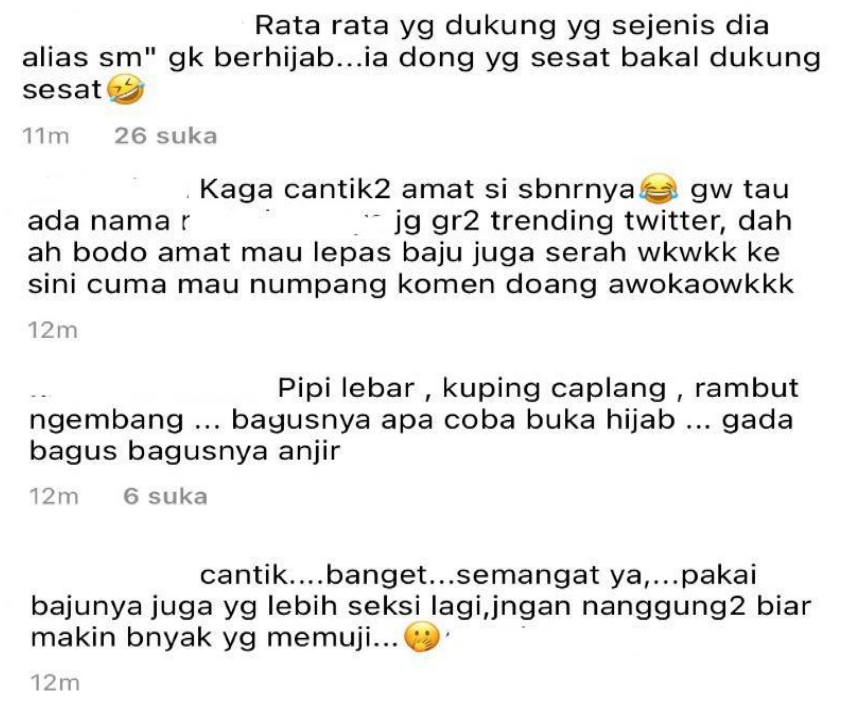

Gambar 9. Komentar Bullying dan Hate Speech pada Kasus Rachel Vennya

Sumber: Instagram Rachel Vennya (@rachelvennya)

Gambar 9 menunjukkan bahwa masyarakat secara sadar melakukan bullying, dan hate speech dengan membawa konteks agama "hijab" dan juga melakukan body shaming. Perilaku ini jelas merugikan Rachel, padahal apa yang dilakukan olehnya merupakan keputusannya sendiri dan tidak merugikan siapapun. Hal ini dibuktikan berdasarkan kutipan wawancara antara Rachel dan Boy William, Rachel menjelaskan bahwa keputusan yang dibuat saat ini bukanlah sikap yang pantas untuk dicontoh dan Rachel menyadari bahwa keputusannya dalam melepas hijab adalah keputusan yang dibuat sendiri dan tidak merugikan siapapun. ${ }^{26}$

Kasus bullying dan hate speech lain juga terjadi kembali di kalangan artis. Baru-baru ini, instagram dihebohkan dengan kasus Nissa Sabyan yang diduga sebagai perusak rumah tangga dari Ririe Fairus dan Ayus Sabyan. Ayus Sabyan merupakan personel dari grup musik Gambus Sabyan yang juga teman satu grup Nissa. Peristiwa ini bermula dari unggahan tangkapan layar seorang pengguna instagram merekam Ririe Fairus sedang berada di Pengadilan Agama Jakarta Utara, dan diketahui sedang menggugat cerai Ayus Sabyan. Isu perselingkuhan yang terjadi di antara Nissa dan Ayus juga dibenarkan oleh keluarga Ayus, dan perselingkuhan ini telah terjadi selama dua tahun.

Sejak kasusnya menjadi viral, Nissa mulai menghilang dari instagram. Kejadian ini membuat netizen melakukan serangan komentar bullying dan hate speech di semua foto yang diunggah Nissa di instagramnya. Berbagai macam kalimat yang dibuat di kolom komentar foto Nissa mayoritas berisi komentar bullying dan hate speech. Adapun contoh komentar bullying dan hate speech dari masyarakat pada kasus Nisa dapat dilihat pada Gambar 10.

\footnotetext{
${ }^{26}$ Boy William, "Lepas Hijab Rachel Vennya"
} 


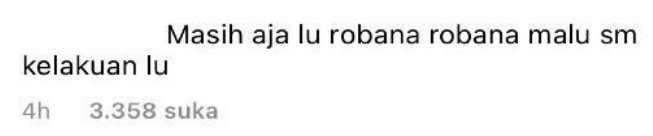

Penyanyi religius kelakuan roh halus i suka

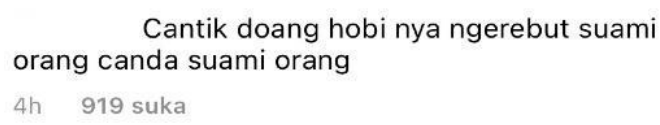

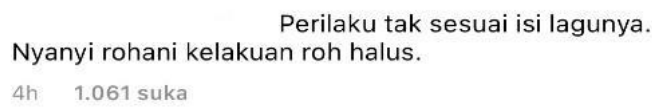

Perilaku tak sesuai isi lagunya. Nyanyi rohani kelakuan roh halus. 4h 1.061 suka

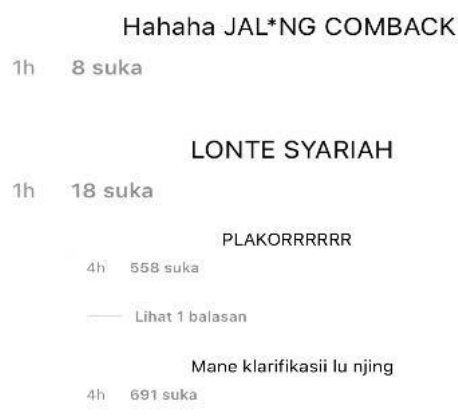

Gambar 10. Komentar Bullying dan Hate Speech pada Kasus Nissa Sabyan Sumber: Instagram Nissa Sabyan (@nissa_sabyan)

Gambar 10 menunjukkan komentar dengan kata-kata kasar yang terjadi pada kasus Nissa Sabyan dilakukan dengan sengaja dan secara sadar oleh masyarakat. Dalam hal ini masyarakat terlihat begitu antusias memberikan hujatan pada kolom komentar di setiap foto Nissa Sabyan. Peristiwa ini tentunya membuat Nissa Sabyan merasa tidak nyaman, dan tetap tidak melakukan upaya klarifikasi untuk menolak tuduhan yang diberikan kepadanya.

\section{Upaya yang Dilakukan untuk Mengurangi Kasus KBGO}

Berbagai upaya sudah banyak dilakukan oleh masyarakat yang mulai menyadari dampak dari KBGO dalam kehidupan sehari-hari. Misalnya, di instagram banyak dibuat akun khusus sebagai wadah untuk korban KBGO berbagi kisah yang pernah dialaminya, melakukan seminar daring (webinar) di masa pandemi COVID-19, dan membuat kampanye dengan poster di instagram. Pada dasarnya, korban yang mengalami KBGO biasanya tidak berani untuk berkata jujur jika sedang mengalami pelecehan. Hal ini tentu merugikan korban, dan pelaku akan terus melakukan hal yang merugikan lainnya dan jumlah korban kasus KBGO akan terus bertambah. Korban yang tidak berani untuk mengungkapkan hal tersebut biasanya disebabkan karena kebingungan, rasa malu, dan hilangnya rasa percaya diri, sehingga banyak dari korban lebih memilih untuk diam. Adapun beberapa contoh akun instagram yang dibuat untuk fokus terhadap kasus KBGO ditunjukkan pada Gambar 11. 
Fitria Cita Dirna

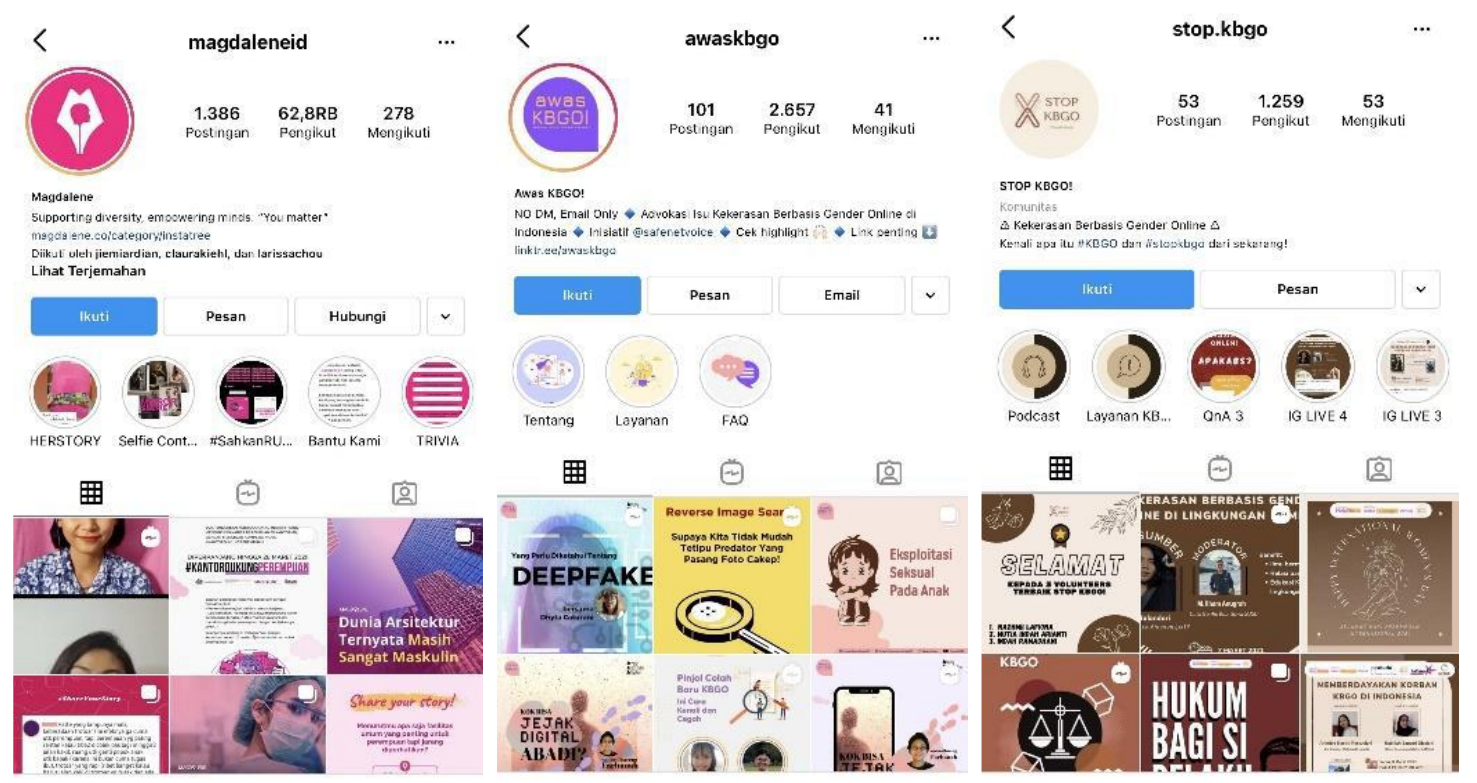

Gambar 11. Contoh akun instagram yang fokus terhadap kasus KBGO (Sumber : Instagram)

Gambar 11 menunjukkan beberapa contoh akun instagram, yang dibuat untuk fokus terhadap kasus KBGO memiliki jumlah followers yang cukup banyak. Seperti pada akun@magdalene.id yang memiliki followers sebanyak 62,8 ribu. Akun ini merupakan media online yang berisi artikel dan podcast perempuan, feminisme, seksualitas, lifestyle, beauty, sosial, politik, yang berperspektif gender. Munculnya akun-akun yang berfokus terhadap gender khususnya KBGO bertujuan untuk memberikan edukasi kepada masyarakat, mengajak masyarakat untuk lebih peduli terhadap sesama, dan saling membantu khususnya dalam menurunkan kasus KBGO di Indonesia.

Secara keseluruhan, penulis dapat mengatakan bahwa media sosial instagram memberikan pengaruh terhadap kasus KBGO yang terjadi di Indonesia. Penggunaan media sosial instagram meningkat selama pandemi COVID-19 dengan jumlah pengguna mayoritasnya adalah perempuan. Pandemi COVID-19 menyebabkan masyarakat banyak melakukan aktivitas secara daring (online), sehingga memiliki waktu luang lebih banyak daripada masa sebelum terjadi pandemi COVID-19. Waktu luang tersebut digunakan untuk mengakses jejaring sosial media seperti instagram yang dapat digunakan untuk menyimpan foto, video, dan berinteraksi dengan orang lain.

Di sisi lain, penggunaan instagram juga dapat digunakan untuk mengakses berita yang lebih cepat dibandingkan televisi, atau surat kabar yang membutuhkan waktu lebih banyak untuk diedit sebelum berita dapat dibaca atau didengar oleh masyarakat. Sehingga, saat kasus-kasus viral yang terjadi di instagram, para pengguna yang mengetahui berita tersebut ikut menanggapi dengan menambahkan komentar di unggahan berita yang sedang viral, atau juga pada kolom komentar akun asli sang artis yang sedang terkait suatu kasus tertentu. Komentar yang ditambahkan berbagai macam, ada positif dan ada yang pula negatif. Komentar negatif berisi ujaran kebencian, pelecehan, hingga bullying. Peristiwa pelecehan dengan komentar kasar serta pelanggaran privasi ini merupakan jenis kasus KBGO yang banyak terjadi di instagram. 


\section{KESIMPULAN DAN REKOMENDASI KEBIJAKAN}

Kesimpulan

Media sosial instagram berpengaruh terhadap peningkatan kasus KBGO di masa pandemi COVID19. Di sisi lain, upaya-upaya juga telah dilakukan untuk menurunkan tingkat KBGO seperti membuat akun khusus sebagai wadah untuk korban KBGO berbagi kisah yang pernah dialaminya, melakukan seminar daring (webinar) di masa pandemi COVID-19, dan membuat kampanye dengan poster di instagram. Secara keseluruhan, Peristiwa pelecehan dengan komentar kasar serta pelanggaran privasi merupakan jenis kasus KBGO yang banyak terjadi di instagram.

\section{Rekomendasi Kebijakan}

Rekomendasi kebijakan dari penulis terbagi menjadi tiga yaitu 1) Untuk masyarakat awam 2) untuk korban dan 3) untuk yang mengetahui kasus KBGO (pendamping korban). Sebagai masyarakat awam yang dapat kita lakukan adalah a) menjadi proaktif untuk mengetahui tentang KBGO b) mengikuti webinar yang membahas tentang kasus KBGO c) menjaga privasi di media sosial d) selalu meyakinkan diri sendiri untuk tidak mau diperlakukan buruk oleh orang lain e) menjaga sikap dalam menggunakan sosial media f) berhati-hati dalam mengunggah foto diri g) bijak dalam menggunakan sosial media.

Untuk korban, penulis dapat merekomendasikan untuk a) berani mengungkapkan apa yang terjadi b) meminta bantuan kepada orang yang dipercaya dan lembaga hukum yang khusus menangani kasus KBGO c) menyimpan atau merekam percakapan yang terjadi dengan pelaku yang dapat digunakan sebagai bukti d) melaporkan dan memblokir pelaku e) dapat melihat situasi, bila memungkinkan untuk melakukan perlawanan dengan tegas agar pelaku sadar bahwa kita tidak bisa dilecehkan.

Rekomendasi terakhir yang dapat penulis sampaikan untuk orang yang mengetahui kasus KBGO agar dapat menjadi mediator antara korban dan lembaga yang menangani kasus KBGO. Pada sebagian korban yang mengalami kasus KBGO akan sangat malu dan tidak percaya diri, sehingga butuh motivasi yang kuat untuk meyakinkan kembali korban tersebut. Selain itu juga dapat melakukan kampanye solidaritas sebagai aksi menyebarkan kesadaran akan keberadaan KBGO.

\section{DAFTAR PUSTAKA}

\section{E-book}

Komnas Perempuan.2021. Perempuan dalam Himpitan Pandemi: Lonjakan Kekerasan Seksual, Kekerasan Siber, Perkawinan Anak, dan Keterbatasan Penanganan di Tengah COVID-19. Catahu 2021 : Catatan Tahunan Kekerasan terhadap Perempuan Tahun 2020, 1-138

Landsverk, Kjell H. 2014. The Instagram Handbook 2014 Edition. United Kingdom: PrimeHead Limited

Winkelmann, S (ed). 2012. The Social Media (R)evolution? Asian Perspectives On New Media. Singapore: Konrad-Adenauer-Stiftun 
Artikel Berita atau Majalah

APJII. 2020. "Survei Pengguna Internet APJII 2019-Q2 2020 : Ada Kenaikan 25,5 Juta Pengguna Internet Baru di RI." Buletin APJII, Edisi 74, Nov

Komara, Indra. 2020. "Komnas Perempuan: Gisel Korban Penyebaran Konten Intim, Tangkap Penyebarnya." detikNews, Desember https://news.detik.com/berita/d-5314496/komnasperempuan-gisel-korban-penyebaran-konten-intim-tangkap-penyebarnya.

Rizaldy, Reza. 2020. "Kasus Gisella: Gimana Sikapi Kekerasan Gender Online Biar Gak Norak." Opini.id, November 2020. https:/opini.id/sosial/read-15219/kasus-gisella-gimana-sikapikekerasan-gender-online-biar-gak-norak

Velarosdela, Rindi Nuris. 2020.“Berstatus Tersangka Video Syur, Apakah Gisel Anastasia Ditahan?." Kompas.com, Desember https://megapolitan.kompas.com/read/2020/12/30/08274881/berstatus-tersangka-videosyur-apakah-gisel-anastasia-ditahan?page=all.

Konten Situs Web

Boyd, Danah. 2009. "Social Media is Here to Stay... Now What?” Microsoft Research Tech Fest, Redmond, Washington https://www.danah.org/papers/talks/MSRTechFest2009.html

Hinson dkk. 2018. "Technology-Facilitated Gender-Based Violence: What Is It, And How Do We Measure It?" Washington D.C. International Center for Research on Women. http://www.svri.org/sites/default/files/attachments/2018-07-

24/ICRW_TFGBVMarketing_Brief_v8-Web.pdf

Kemenkes RI. 2020. "Pertanyaan dan Jawaban terkait COVID-19." https://www.kemkes.go.id/article/view/20031600011/pertanyaan-dan-jawaban-terkaitcovid-19.html

LBH APIK Jakarta. 2021. "Siaran Pers : Refleksi Hari Kartini ditengah Pandemi : Perempuan dan Kerentanan Terhadap Kekerasan yang Meningkat Dalam Masa Pandemi Covid-19." Diakses pada Maret 8, 2021, dari https:/www.lbhapik.org/2020/04/siaran-pers-refleksi-harikartini.html

Cat, Napoleon. 2021. "Social media users in Indonesia” https://napoleoncat.com/stats/instagramusers-in-indonesia/2021/02

SAFEnet. 2019. Memahami dan Menyikapi Kekerasan Berbasis Gender Online: Sebuah Panduan (Vol. 2). 2019. https://id.safenet.or.id/wp-content/uploads/2019/11/Panduan-KBGO-v2.pdf

WHO. 2020. “Critical Preparedness. Readliness and Response Actions for Covid-19." 2020. Diakses pada Maret 10, 2021, https:/www.who.int/publications/i/item/criticalpreparedness-readiness-and-response-actions-for-covid-19 
Artikel Jurnal

Buana, Dana R. 2020. “Analisis Perilaku Masyarakat Indonesia dalam Menghadapi Pandemi Virus Corona (Covid-19) dan Kiat Menjaga Kesejahteraan Jiwa." Jurnal Sosial dan Budaya Syar-i 7, No. 3 (2020) 217-226. DOI: 10.15408/sjsbs.v7i3.15082

Cahyono, Anang S. 2016. "Pengaruh Media Sosial Terhadap Perubahan Sosial Masyarakat di Indonesia." Jurnal Publiciana 9, No 1. (2016) 140-157.

Djalante, R. dkk. 2020. "Review and Analysis of Current Responses to Covid-19 in Indonesia: Period of January to March 2020." Progress in Disaster Science, 100091, (2020) 1-9. https://dx.doi.org/10.1016\%2Fj.pdisas.2020.100091

Dong Y, dkk. 2020. "Epidemiology of Covid-19 Among Children in China." American Academy of Pediatrics, (2020) DOI: https://doi.org/10.1542/peds.2020-0702

Kaplan, Andreas M, dan Haenlein, Michael. 2010. "Users of the world, unite! The challenges and opportunities of Social Media.” Business Horizons 53, no. 1 (January-February 2010) : 5968. https://doi.org/10.1016/j.bushor.2009.09.003

Tan, Wenjie, dkk. 2020. "A novel coronavirus genome identified in a cluster of pneumonia cases — Wuhan, China 2019 - 2020." China CDC Weekly 2 , no. 4 (2020) :61-62. http://weekly.chinacdc.cn/en/article/id/a3907201-f64f-4154-a19e-4253b453d10c

Tosepu, Ramadan, dkk. 2020. "Correlation between weather and Covid-19 pandemic in Jakarta, Indonesia." Sci. Total Environ 725, 2020 https://doi.org/10.1016/j.scitotenv.2020.138436

Media Sosial

William, Boy. 2021. "LEPAS HIJAB! RACHEL VENNYA BUKA SUARA KE BOY WILLIAM! | \#DrinksWithBoy Eps.9” Youtube, 2021 https://youtu.be/Q9_RKs1NLZk 